\title{
Developing the Corporate Management Model on the Basis of State-Private Partnership in Energy Supply to the State and Municipal Budget Organizations ${ }^{1}$
}

Kramin T.V.a

Fatkheiv A.M.b

Kramin M.V.c

Grigoryev R.A.d

\author{
acd Institute of Economics, Management and Law, Kazan, Russian Federation, 420111 \\ ${ }^{b}$ Kazan Federal University, Institute of Management, Economics and Finance, Kazan, 420008, Russia
}

\section{Doi:10.5901/mjss.2015.v6n1s3p105}

\begin{abstract}
The article presents the research results of one of the topical issues of corporate management - interaction between a corporation and state in the frameworks of state-private partnership for increasing the energy efficiency and energy saving in the budget sphere. The advanced model of corporate management offers ways of developing the state-private partnership mechanism in this sector.

Keywords: Corporate management; state-private partnership; energy efficiency; energy saving; energy servicing company; energy servicing contract; energy servicing market.
\end{abstract}

Under the speeding globalization and post-industrial economic development, the institution of corporate management is rapidly developing both in Russia and abroad. The corporate management efficiency becomes one of the key factors of competitiveness of both a particular company and the national economy as a whole (Blackburn, 1994). The article presents the research results of one of the topical issues of corporate management - interaction between a corporation and state in the frameworks of state-private partnership for increasing the energy efficiency and energy saving in the budget sphere. The advanced model of corporate management offers ways of developing the state-private partnership mechanism in this sector.

In previous works we proved that corporate management must be based on systemic approach. The previous results allow to form a complex system of corporate management, to describe its elements and interaction between them (Engelen, 2002). The system management will use the cost (Othman \& Rahman, 2009) and institutional approaches (Aguilera \& Jackson, 2003).

The classical corporate management system is based on the division of owner and manager functions (Corbett, 1998; Fama \& Jensen, 1983a, 1983b). The main role of the owners (shareholders) is to appoint the Board of Directors. The main role of the Board of Directors, which is the leading body in corporate management of an organization, is to appoint the top managers and further control their performance (Molz, 1985). The recent practice, both in Russia and abroad, shows that this mechanism is inefficient, as it does not allow the corporation authorities to make operative decisions and create an efficient system of risk management in corporations, which is extremely necessary during financial instability.

The new corporate management system should be based on cooperation and integration of management at all levels of the corporation. Besides, the corporate management system, as it was shown before, should include all stakeholders of the corporation (Freeman, Harrison, \& Wicks, 2007; Hill \& Jones, 1992; Jones, 1995; Post, Preston, \& Sauter-Sachs, 2002).

\footnotetext{
1 The work is carried out with the financial support of the Russian Humanities Scientific Fund within a research project 10-02-00079a. 


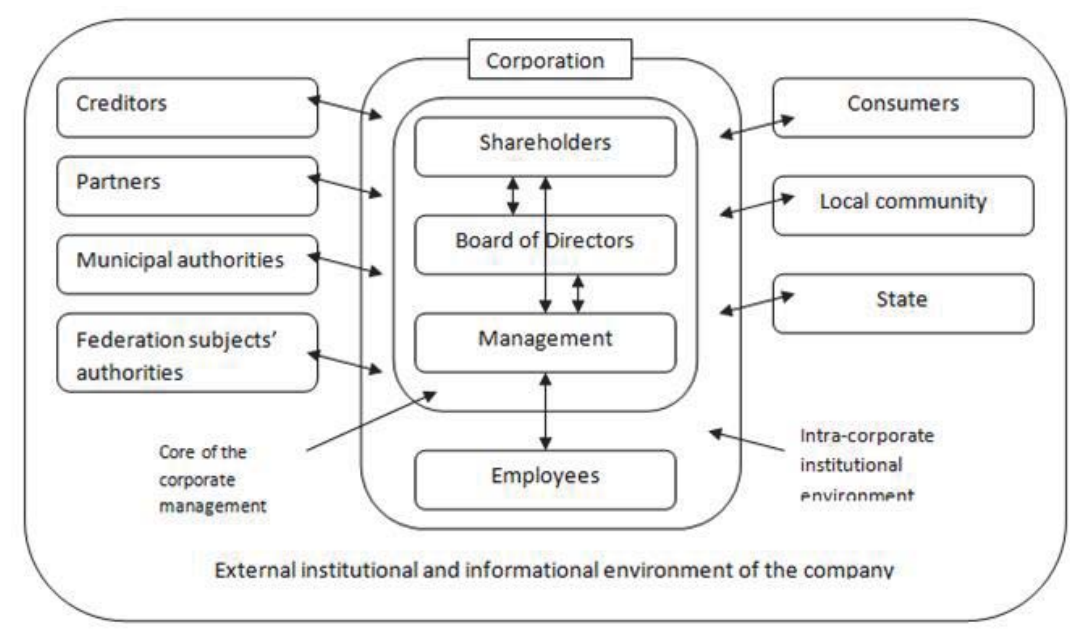

Fig.1 Corporate management system in post-industrial economy

The post-industrial economy is characterized by the growth of significance of the corporations' intangible assets, their intellectual capital (Malhotra, 2001; Skyrme \& Amidon, 1998). In many modern corporations the independent directors have no experience in the markets of these corporations' products (their major activities refer to other sector). This has a negative effect on the efficiency of the Board of Directors in general. Moreover, it is necessary to systemically manage the competences of the Board of Directors.

Other elements of corporate management are considering and using the intra-corporate institutional factors, adaption to the external institutional environment of a corporation (Hoskisson, Johnson, Tihanyi, \& White, 2005; Judge \& Zeithaml, 1992; Pfeffer \& Salancik, 2003).

Taking the above factors into account, we can view the corporate management system as follows (see Fig. 1), (T. Крамин, Крамин, \& Петрова, 2011).

Unlike the traditional corporate management system, the proposed one broadens the shareholders' authorities (to simplify the model, we will here and further consider a corporation to be a joint-stock company). Corporate management should be based on the balanced satisfaction of all stakeholders' interests (Clarkson, 1995; Donaldson \& Preston, 1995; Freeman \& Edward, 1984; Jawahar \& McLaughlin, 2001). Here lies the great and so far not fully implemented potential of the corporations' efficiency growth. Shareholders should take an active part in this sphere of corporate management.

Bearing in mind that stakeholders play an important role in corporate management, and interaction with them largely determines the efficiency of corporate management, stakeholders are one of the key elements of corporate management system (Ireland \& Hitt, 1999; Jensen, 1991; White, 2009). The corporate management should include the mechanism of revealing and predicting the key stakeholders' interests and using them as the basis for balancing and satisfying the stakeholders' interests (Buck, Filatotchev, \& Wright, 1998; Gourevitch \& Shinn, 2005; Ho, 2005). To fulfil this task a number of intra-corporate institutions should be formed:

1) Institutions for the stakeholders' interests balancing;

2) System of standards of interactions with stakeholders (shareholders, employees, consumers, partners, etc.);

3) Formal and informal mechanisms of disambiguation.

The main directions of activity in accounting and satisfying the stakeholders' interests are:

1) Determining the company's key stakeholders;

2) Accumulation and systematization of information about the key stakeholders' interests;

3) Evaluating efficiency of a corporation's activity on satisfying the stakeholders' interests, both from the point of view of usefulness for a corporation and from the point of view of stakeholders;

4) Tracing the changes in the interests of corporation stakeholders;

5) Correction of the strategy of interaction with stakeholders and the corporate strategy as a whole.

Thus, the dynamics of the corporate strategy development will be determined not only by the dynamics of the market conjuncture development and the priorities of the corporations' shareholders, but also the stability of the key stakeholders' interests, the degree of their influence on the corporation activity and the process of developing ambiguity in their relations with the corporation.

The stakeholders' interests are determined by the factors of their utility. For the further analysis of the corporate 
management system, they should be viewed in more detail.

The shareholders' utility factors are the level of their profitability and the degree of risk of no return of their investments. The employees' utility factors are the volume of their work, the level of awards for their work, and the working conditions.

The consumers' utility factors are the price of goods and services, their quality and convenience of use. For the corporate partners it is important that the corporation fulfils its contract obligations, and flexibly corrects the contract terms if necessary.

The creditors are interested in the transparency of the corporation's activity, the ability to duly and correctly trace the dynamics of its key financial indicators and the financial position as whole, in order to estimate the risks in the corporation's activity.

The local population is interested in preserving the favorable ecological conditions in the territory of the corporation's activity (level of noise, pollution, etc.).

The authorities of various levels are interested in budget income as a result of the corporation's activity, the growth of employment and incomes of the population, the increase of the social protection of the population, the creation of infrastructure, the minimization of negative consequences of the corporation's activity for the environment, etc.

The above examples allow to conclude that the utility factors are not always tangible. However, the majority of the above intangible factors can be evaluated by their cost. It is the cost approach that gives a common criteria for their evaluation, management and making other managerial decisions.

Taking everything above-mentioned into account, we should extinguish the following hierarchical levels of the corporate management system:

1) Factors of utility of the corporation and its stakeholders;

2) Competences of corporate management subjects;

3) System of managerial decisions.

Concluding the characteristics of the corporate management system, we should highlight that its main elements are the intra-corporate institutional environment and the external institutional and informational environment of a corporation.

The functioning of the above model can be illustrated by the example of energy servicing companies with the state.

Let us view the prerequisites and mechanisms of the private companies' interaction with the state in the field of energy supply and energy saving in budget sphere, which are especially acute due to the requirement of the law to reduce energy consumption in budget organizations by 15\% on the basis of quantity till 2014 (Law \#261-Ф3 "On energy saving and energy efficiency increase.", 2009) .

According to the materials of the European Bank for Reconstruction and Development, prepared for the session of Expert council on legislative on state-private partnership of the Russian State Duma Committee on economic policy and entrepreneurship, of April 18, 2011 (EBRR, 2011), the financing of energy supply and other communal resources for state and municipal budget sphere, about $4-5 \%$ of the Russian consolidated budget are spent. It is necessary to note that this financing comes only from the budget sources of inefficient resulting consumption of the resources. Moreover, the efficiency of energy supply of budget-financed buildings in the Russian Federation is significantly lower than in Europe: our norms of energy consumption is $40-50 \%$ higher than the European ones, while the actual consumption of the budgetfinanced buildings in Russia is much higher than the normative one.

Inefficiency and high level of budget expenses for communal resources together with the growth of internal prices for energy leads to the need to increase the energy efficiency in the budget sphere. Very important are also the issues of reconstruction of the budget and social venues and providing the comfortable exploitation of these venues. These are, first of all, schools, kindergartens, hospitals and other establishments for the least protected groups of the Russian population. Solving these tasks demands large investments. At the same time, the possibilities of attracting the local and regional budget funds are limited; there are also limitations of non-budget financing.

A prospective direction of the set task is using the mechanism of state-private partnership ${ }^{2}$ in the sphere of energy efficiency increasing and budget sphere servicing (Андреев \& Моргунов, 2008; Романова, 2012). According to the expert estimations by the European Bank for Reconstruction and Development, the current energy consumption in the budget sphere can be reduced by $30-40 \%$ with the help of resources saving mechanisms. Such measures save a lot of energy and can be used for financing the energy saving. Elaborating the appropriate legislation for private energy servicing companies (ESC) (specialized energy servicing companies, equipment suppliers, energy suppliers, engineering companies, etc.) will create the conditions for investing into the techniques for energy efficiency in budget sphere. The

2 See for instance (Белицкая, 2011; Варнавский, 2005). 
ESC investments will be returned from the budget economy during the action of energy servicing contract (the contract is signed by ESC and the municipality and the budget organization on the competitive basis).

It should be note that the budget organizations usually lack technical equipment, experience and competences for energy supply optimization. Attracting specialized ESC will allow them to focus on their main activity.

Since 2009 the institutional environment of energy servicing contracts has been rapidly developing (the development of legislation in energy servicing), which provides conditions for implementing the mechanisms of stateprivate partnership in the sphere of energy efficiency: the notion of "energy servicing" is introduced; the general requirements for the content and order of signing the energy servicing contracts; possibility is ensured to sign long-term (longer than the three-years budget cycle) energy servicing contracts; possibility to use the budget funds, saved by energy saving, for payments on energy servicing contracts; rules are determined to form the maximal price of energy servicing contract and carrying out the municipal auctions for signing the energy servicing contracts in compliance with the legislation on placing orders for state and municipal needs (94- $\$ 3)$.

The adopted legislative base makes a solid foundation for signing long-term energy servicing contracts and provides guarantees of investment return to energy servicing companies and banks, which are financing them, from budget economy. At the same time, there are legal restrictions and other problems to be solved in order to create conditions for competitive market of energy servicing in Russia.

As a result of thorough investigation of these issues, the European Bank for Reconstruction and Development specialists made the following proposals for improving the legislation in the above sphere, which are the most topical:

1. To make amendments in 94- $\$ 3$ to abolish the consumer's liability to require the contract execution if the initial (maximal) price of the contract exceeds $50 \mathrm{mln}$ rubles.

2. To change Article 56 of $94-\Phi 3$ to enable the increase of the maximal price of the contract by the part of exploitation costs for communal infrastructure servicing, which will be reduced as a result of energy servicing measures.

3. To include the energy servicing into Article 149 of the Tax Code, containing the list of operations freed from taxation on added value.

4. To make amendments in part 2 of Article 24 of $261-\Phi 3$, aimed at preserving the existing amounts "communal services" financing for the budget/autonomous organizations and state enterprises who signed energy servicing contracts.

The materials prepared by the European Bank for Reconstruction and Development also pose additional questions, which should be studied for the further stimulation of energy servicing business in Russia:

1. Risks of inappropriate services rendered by resource companies are imposed on ESCs.

2. It is necessary that a consumer monthly initiates a complex procedure of negotiating the volume of energy consumption reduction with the resources supplier, which can be combined with the significant for consumption reduction of energy and other resources.

3. At present, the rules of signing the energy servicing contracts do not regulate the ESC participation in rendering servicing of equipment installation (which can require consumer's payment additional to the price of the energy-servicing contract). At the same time, to obtain the maximal economy of the energy-efficiency equipment introduction, the correct professional exploitation of this equipment is required.

4. There are high political risks in cases, when the terms of consumer's liability exceeds the term of "political cycle". This fact is destimulating for banks when they open "long" credit lines for energy servicing companies. It is necessary to reduce these risks by developing the mechanisms of state support in the form of state guarantees institutions, creating the refinancing funds of energy servicing contracts, etc.

Thus, the institutional environment of energy servicing contracts in Russia is far from the ideal. It should be thoroughly reformed in order to reduce risks and transactional costs of all participants of such contracts.

The traditional energy service is not the only tool of energy saving in the budget sphere. There are other possibilities of attracting the private capital into the energy efficiency budget sector. Leasing is most popular among them. Besides, energy servicing, popular in developed markets is often discussed, i.e. energy servicing of the type of guaranteed economy. Here we should consider the long-term energy servicing contracts not only with the companies, independently implementing the energy-saving measures and obtaining the return investments during the contract period (called ESCon-1), but also with another type of companies (ESCon-2). ESCon-2 does not finance the project (delivery services, installation and maintaining are financed from the budget). However, unlike ESCon-1, such companies give a guarantee of economy ("performance bond") to the customer (state establishment, for example).

Thus, a customer, having funds for equipment and services, obtain an important advantage in comparison with the ordinary contracts for equipment delivery: the risks of the wrong choice of technical solution and its maintenance are 
imposed on the customer in case of classical scheme, while in case of energy servicing of the second type they are imposed on the executor, i.e. on ESCon-2.

The energy servicing contract of type 2 is especially beneficial for the Russian conditions, as it eliminates a number of risks of its participants. It should be viewed as the main type of an energy servicing contract in the period of forming of this kind of state-private partnership.

To introduce the type 2 energy servicing contracts into the Russian practice, it is necessary to confirm them institutionally as amendments in Law 94- $\$ 3$ on state purchases and budget code. Besides, the contract relations of energy servicing of type 2 should be thoroughly elaborated.

The above example of an energy servicing contract brightly illustrates the functioning of the described advanced model of corporate management, which implies participation of the majority of stockholders shown in Fig.1. Besides, the institutional environment, shown in the model, is very significant for contract.

The main conclusions of the research are listed below:

1. There is no strategy and concept of state-private partnership development in Russia, both at federal and regional levels (including in energy servicing).

2. There is no system both in signing particular contracts of state-private partnership (including energy servicing contracts), and in developing the legislative and normative-legal base of state-private partnership in Russia.

3. Most problems in energy servicing development are connected with the lack of stimuli for its implementation in its potential participants, with high risks and transactional costs while its implementation.

The essence of our proposals is to amend the previous schemes of state-private partnership development (in particular, energy servicing contracts (ESCon)) to maximize the stimuli, minimize the risks and transactional costs for all its potential participants. The above mentioned materials (viewed at the session of May 18, 2011) contain no proposals for stimulating the municipalities for ESCon implementation (though, as experts note, the municipalities are satisfied with the present position). Besides, the state risks are not considered, connected with the potential ESC inefficiency. The selection of ESC is made on traditional tendering foundations. It may provide efficient selection at municipal level. However, ESC, at least in the budget sphere, should be based on the advanced achievements and best practices in the sphere of energy saving at federal level.

To stimulate corporate management based on state-private partnership in the energy servicing market it is necessary:

1. to form the state-private partnership conception: to define the society demands in state-private partnership, the interests of the main potential participants, the resource limitations, to systemically characterize the stateprivate partnership relations (as broadening and amending the Law \#115- $\$ 3$ On concession agreements).

2. to form the strategy of state-private partnership development and a detailed program for its implementation. In particular, in the sphere of ESC activity it is appropriate to define the stages of energy servicing market development and specific measures within each stage (see below).

3. To ensure the systemic character of activity in the energy-efficiency sphere, which consists in the complex problem-solving. The problem of energy saving should be solved at the state level. In this process the state should act as a coordinator. Due to that, a cluster should be formed for ensuring the efficiency of energy servicing projects. The cluster should accumulate the best technologies, business processes and managerial innovations, offering the high-technology solutions, standards and equipment to energy servicing companies. At the regional level the cluster should include the municipalities, sectoral scientific-research institutes, project organizations, universities, engineering companies, etc.

4. to continue work on creating the Federal law on state-private partnership, which would promote the procedure of making amendments to the federal legislation (to federal laws 261- $\$ 3,94-\Phi 3$, to the Russian Taxation Code, etc.). The law should contain the definition of the state-private partnership, list the main features, forms and mechanisms of state-private partnership. It should also eliminate the so-called "political risks" of ESCon and promote the procedure of ESC financing.

5. To ensure the staged introduction of the institutions of energy servicing contracts into practice, considering the high risks for all participants.

\section{References}

Aguilera, R. V., \& Jackson, G. (2003). The cross-national diversity of corporate governance: Dimensions and determinants. Academy of management Review, 28(3), 447-465.

Blackburn, V. L. (1994). The effectiveness of corporate control in the US. Corporate Governance: An International Review, 2(4), 196- 
202.

Buck, T., Filatotchev, I., \& Wright, M. (1998). Agents, stakeholders and corporate governance in Russian firms. Journal of Management Studies, 35(1), 81-104.

Fakhrutdinova E., Severyanov O., Shigabutdinov A., Fakhrutdinov R. The crisis of 1998 in Russia: political intervention and its implications. Life Science Journal 2014; 11(6s): 442 - 447.

Fakhrutdinova E.V., Kolesnikova J.S., Suleimanov T.D., Khalikov A.L., 2014. The interrelation of the problems of the youth labour market and the "brain drain". Life Science Journal; 11(6s): $473-477$.

Fakhrutdinova, E., Karasik, E., Safina, L., Miropol'skaya, N. The role of social protection in formation of quality of work life// World Applied Sciences Journal.Volume 27, Issue 13, 2013, Pages 72-76.

Kamasheva A., Karasik E., Kolesnikova J., Salyakhov E., 2013. Discrimination and Inequality in the Labor Market// Procedia Economics and Finance Volume 5, pp. 386-392.

Karasik E., Yagudin R., Leukhin A., Zagidullina V. Improvement of social policy towards the disabled in the Russian Federation. Life Science Journal 2014; $11(6 s): 478-481$.

Freeman, R. E., Harrison, J. S., \& Wicks, A. C. (2007). Managing for stakeholders: Survival, reputation, and success: Yale University Press.

Gourevitch, P. A., \& Shinn, J. (2005). Political power and corporate control: The new global politics of corporate governance: Princeton University Press.

Hill, C. W., \& Jones, T. M. (1992). Stakeholder-agency theory. Journal of Management Studies, 29(2), 131-154.

Ho, C. K. (2005). Corporate governance and corporate competitiveness: an international analysis. Corporate Governance: An International Review, 13(2), 211-253.

Hoskisson, R. E., Johnson, R. A., Tihanyi, L., \& White, R. E. (2005). Diversified business groups and corporate refocusing in emerging economies. Journal of Management, 31(6), 941-965.

Vakhitova T.M., Gadelshina L.A., Grigorieva L.L. Evaluation of the Relationship between Integrational Processes and Socio-Economic Development of Regions of Russian Federation Under Conditions of Economic Globalization (Based on the Republic of Tatarstan Example)// Mediterranean Journal of Social Sciences.- Vol.5, No12, (2014)-pp.123 - 127.

Khasanov I.Sh. Three-Sector Structure of the National Economy of Russia// Mediterranean Journal of Social Sciences.- Vol.5, No12, (2014)-pp.149- 153.

Varlamova J.A., Larionova N.I. Economic behavior of households: cross-country comparison. Life Science Journal 2014; 11(6s): 409413. 